\title{
A STRATEGIC PLAN FOR DEVELOPING THE BANDA ARCHIPELAGO AS AN ECOTOURISM AND ENVIRONMENTAL CONSERVATION AREAS
}

\author{
RENCANA STRATEGI UNTUK MENGEMBANGKAN KEPULAUAN BANDA \\ SEBAGAI KAWASAN EKOTURISME DAN KONSERVASI LINGKUNGAN
}

\author{
Rudianto*, Armyn Atlanta Putra, Zulqi Fahreza Akbar and Audina Putri \\ Marine Science Study Program, Faculty of Fisheries and Marine Sciences, \\ Brawijaya University, Malang, 65145, Indonesia \\ *E-mail: rudiantoita@gmail.com
}

\begin{abstract}
Banda Islands is located in the eastern part of Indonesia. These islands are rich in coral reefs and fish. This archipelago has been designated by the Indonesian Government as a tourist area. However, the Banda Islands are facing several economic, social and environmental problems. This study aims to provide policy input to local governments in the form of a strategic plan to develop the Banda Islands as ecotourism and environmental conservation. The method used is "Ecotourism Opportunity Spectrum" (ECOS) and the "Conservation Measures Partnership" (CMP) model. The results of this study produce five strategic plans: a) The first priority is to create a working forum; b) the second is the integration of tasks between the parties involved; c) the third priority is the regulation for changes in coastal land; d) fourth priority is mapping of fishing and; e) the fifth priority is alternative livelihoods.
\end{abstract}

Keywords: Banda Archipelago, CMP, ECOS, ecotourism, strategic plan

\section{ABSTRAK}

Kepulauan Banda terletak di bagian timur Indonesia yang kaya dengan terumbu karang dan ikan. Kepulauan ini telah ditetapkan oleh Pemerintah Indonesia sebagai daerah wisata. Namun, kepulauan Banda sedang menghadapi beberapa masalah ekonomi, sosial dan lingkungan. Penelitian ini bertujuan untuk memberikan masukan kebijakan kepada pemerintah daerah dalam bentuk rencana strategis untuk mengembangkan kepulauan Banda sebagai ekowisata dan konservasi lingkungan. Metode yang digunakan adalah "Ecotourism Opportunity Spectrum" (ECOS) dan "Conservation Measures Partnership" (CMP). Hasil penelitian ini menghasilkan lima rencana strategis: a) prioritas pertama adalah menciptakan forum kerja; b) yang kedua adalah integrasi tugas di antara pihak-pihak yang terlibat; c) prioritas ketiga adalah peraturan untuk perubahan tanah pesisir; d) prioritas keempat adalah pemetaan penangkapan ikan dan; e) prioritas kelima adalah mata pencaharian alternatif.

Kata kunci: CMP, ECOS, ekowisata, Kepulauan Banda, rencana strategis

\section{INTRODUCTION}

Conservation, according to Dunster and Dunster (1996), basically involves the management or control of human use of resources (biotic and abiotic) in an attempt to restore, enhance, protect, and sustain the quality and quantity of a desired mix of species, ecosystem conditions, and processes for present and future generations. Ecotourism, therefore, has been described as an answer to this because of its potential for supporting the conservation of natural ecosystems and promoting sustainable local development (Buckley, 1994; Wallace and Pierce, 1996; Lindberg et al., 1997). Natural resource conservation is thus necessary because ecotourism is a form of nature-based tourism and as such, depends on the natural environment for its existence. According to Budowski (1977) stated that tourism can be important to natural resource conservation 
because part of the income from tourism can be reinvested into maintaining natural areas. Yet, despite assurances of improved and alternative livelihood options by conservationists and governments, rural communities often tend to be worse-off following the creation of protected areas and introduction of tourism products due to, among others, inequity in the distribution of tourism benefits (Cobbinah et al., 2017). According to Khoshtaria et al. (2017) areas that function to be developed as ecotourism areas, unique protection of natural diversity, and increased welfare of adjacent residential populations are strategic issues to consider.

To explore the relationship between ecotourism and environmental conservation, a study will be conducted in the Banda archipelago. The problems faced by Banda archipelago as a marine eco-tourism area include: (a) damage of coral reefs due to the use of anchors, the effect of waste and pollution and the mining of coral for building materials; (b) there has been a decline in fish catch and an increase in operational costs for fishing. Banda Archipelago has great potential for marine tourism because the archipelago has beautiful coral reefs, many diving spots, and white sand beaches. However, marine tourism has not been managed optimally and the community has not been involved directly in managing marine tourism. The Banda Archipelago also has a high potential for historical and cultural tourism because of the existence of forts and old buildings from the colonial era and the period of struggle for Indonesian independence; (c) there have been too many jaring bobo (purse seine or encircling nets) operating in the coastal area, which has resulted in overfishing of small fish; (d) there were many tuna longline boats around Banda waters; (e) mining activities were still found in Rhun Island which were done to create embankments and piles of sea waves and abrasion occurring around the settlement. Apart from that, it is also used for building materials on a small scale for households or wall fence. Welly et al. (2012) proposed that to address the pressures existing on these high-valued fishes, effective management needs to be established for Banda waters through the development of a marine protected area network managed by national and local governments, as well as the local community. Therefore, the purpose of this study was to develop a strategic plan for the development of the Banda archipelago as a marine tourism park area. The development of the Banda archipelago does not only pursue economic benefits but what is important is to conserve ecological values based on sustainable development.

\section{RESEARCH METHODS}

\subsection{Time and Place of Research}

The study time is carried out between October and December 2017 by conducting field observations and literature studies. The study areas include 11 Banda islands with a total area of $180.59 \mathrm{~km}^{2}(18,059 \mathrm{ha})$. There are 11 islands included in the Banda Islands, only 5 islands are inhabited by humans. This is due to the size of the inhabited island covering an area of 13.16 ha to 108.63 ha. Banda archipelago is located in the Central Maluku district with 180.59 square kilometers on the Banda Sea inner arc. The archipelago is a remote oceanic archipelago situated in the Banda Sea, eastern Indonesia, at approximately $04^{\circ} 31 \mathrm{~S}$ and $129^{\circ} 54 \mathrm{E}$.

\subsection{Material and Data}

Banda archipelago was analyzed in terms of its potentials from the most dominant coastal ecosystems: environmental sustainability, co-management-based natural resource management and key elements that are key to the successful management of natural resources and human resources, ie institutional development. Coastal areas in Banda archipelago provide multiple ecosystem services such as coral reefs, fish production and recreation in marine parks to human society, which contribute to local 
livelihoods and encourage local and national economic development. The map of the
Banda archipelago which became the object of the research is presented below.

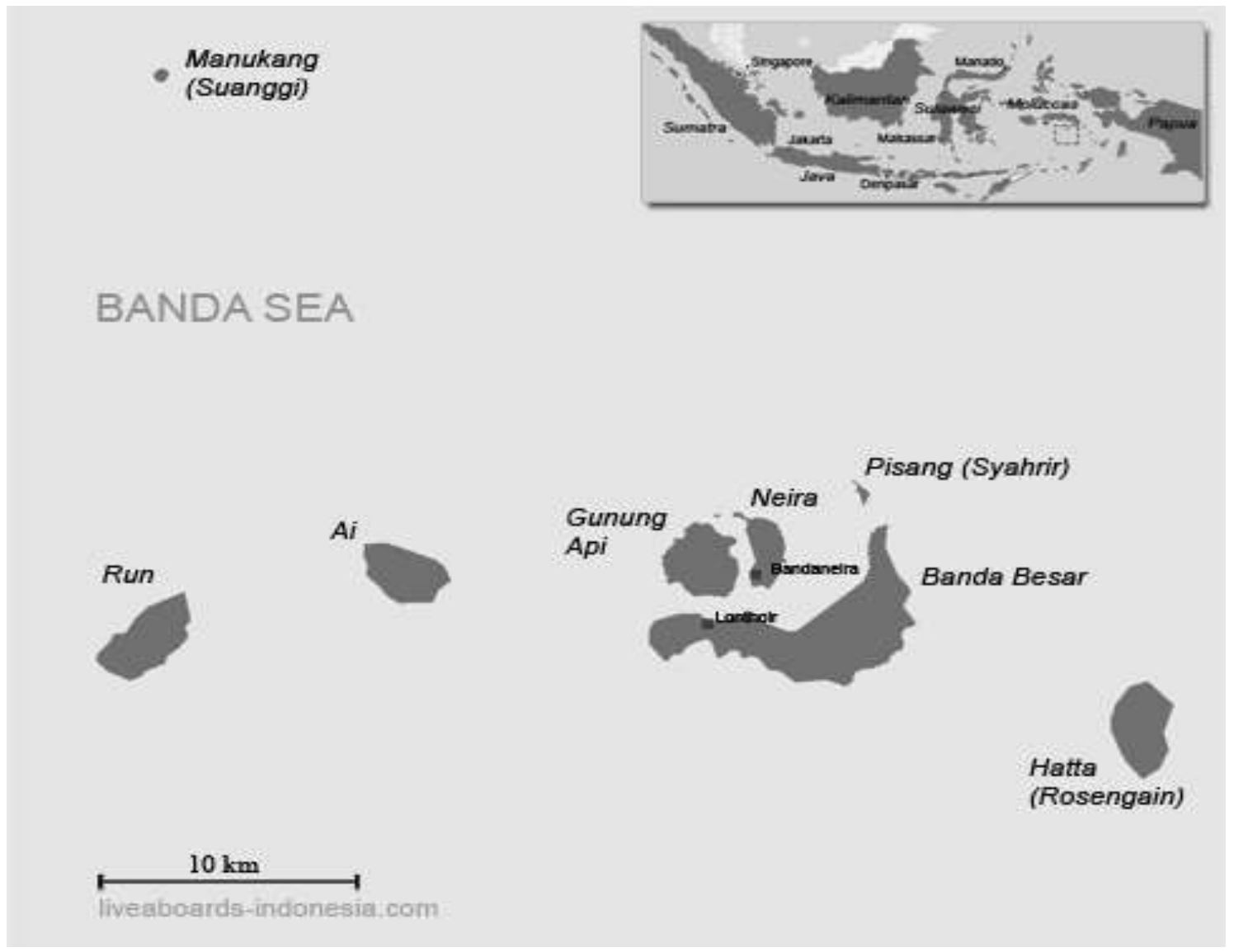

Figure 1. Map of the Banda Islands, Maluku Province, Indonesian.

\subsection{Potential of Coastal Ecosystems}

Banda archipelago was designated as a national conservation area and a sea tourism park with an area of $2500 \mathrm{Ha}$. The potentials of the archipelago include coral reefs, pelagic fishery potential, wildlife potential, and marine conservation areas. The coral reefs spread across six islands in Banda archipelago, from Run Island on the west to Hatta Island, $50 \mathrm{~km}$ to the south. The condition of coral reefs was good, but lowlevel damages can be found.

Welly et al. (2012) stated that the total number of coral species found in the Banda Islands reached 397 species. The fish surveys identified 433 different fish species. Until today, the total number of fish species has reached 683 species. A great number of
Napoleon wrasse was found in the Banda Islands. However, even though the fish are protected under law, they still become targets of fishing. Coral reefs in the Banda Islands are categorized as oceanic reefs, where the reef flats are narrow and directly facing the deep sea. Generally, the coral reef cover and fish abundance in the Banda archipelago are good. In some locations, the cover and abundance are quite high with a high potential for fishing. The best coral cover at the depth of three meters on the Island of Nailaka reaches $88.97 \%$ and the depth of ten meters in the location of Lava Flow (volcano island). Furthermore, the hard coral cover in the Banda Islands is still in good condition. However, from observations, some damages and threats to the coral reefs due to 
destructive fishing were found. Alik et al. (2012) mentioned that the Banda archipelago is surrounded by hundreds of different types of coral reefs. The 2012 marine assessment identified about 310 species of coral reefs and 500 species of fish. The diversity of fish in Banda Marine Park comprised many ancient fish and shellfish species currently conserved such as Napoleon fish.

Banda marine is potential as a producer of small pelagic fish, such as a fish overpass, Bigeye scad (Selar crumenophthalmus), Fringes cale sardine (Sardinella vimbriata), Indonesia oil sardine (Sardinella longiceps) and bloated. Fishing vessels are operated by the engine (inboard and outboard engine). The main target was yellow-tailed tuna (Thunnus albacores) or other pelagic species. Fishermen who operate without engine were mostly traditional fishermen who make a living with simple equipment and some limited captures were sold to local markets. The Banda Sea was identified as one of the important marine conservation priorities in Indonesia (Huffard et al., 2009). The wildlife potential of the area consists of 28 species of birds, 8 species of mammals, 5 species of reptiles, 7 species of insects, 21 species of marine biota and 17 species of natural plants.

Marine Conservation Area comprises Pombo Marine Park island (998 ha); Sea Tourism Park Banda Api (735 ha); Kassa Island Marine Garden Park (1,100 ha); and Banda Marine Reserve $(2,500$ ha $)$ (Directorate General of Sea Spatial Management). Banda geothermal system is thought to be associated with Quaternary volcanism. The heat source in the Banda area is thought to be derived from the remaining heat of the young volcanic cones of the Banda Api Mountain. The results of the gas geothermometer calculations show that the subsurface temperature on the Banda Neira geothermal system is about $260^{\circ} \mathrm{C}$, which can be considered as high enthalpy. Banda Apes fire first erupted on 17 April 1856 and last erupted on May $9^{\text {th }}$. Until the date of May $31^{\text {st }}$, the 1988 eruption occurred at 6 holes.

The Indonesia government issued regulation through the decree of the Minister of Marine Affairs and Fisheries of the Republic of Indonesia Number 58/ Ministry Degree of Fisheries and Marine/2014 which states that to develop aquatic park areas to provide great ecological and economic benefits, a comprehensive and systematic management direction is required. Therefore, a long-term management plan for Banda park is required, to be further elaborated into medium and annual plans.

\subsection{Data Analysis Method}

This research provides inputs for management guidance in the form of strategic plan development of the Banda Islands as a marine ecotourism area. The drafting of the plan should involve the stakeholders at the central and regional levels so that the document can bridge the interests and aspirations of government and society at all levels. Therefore, it is necessary to use Fagence's approach (2015) which proposes that the strategy-formulation process will need to be systematic based on the clear articulation of objectives, a thorough assessment of the available resources, a determination of the market demand, and the creation of an appropriate quantitative, qualitative and geographical strategy. Methods of resource assessment may be used to assess the capabilities and suitabilities of the spectrum of resources which support tourism development, and many of those which are particularly appropriate for the assessment of nature-based resources for ecotourism. Fagence (2015) mentioned that in recent years resources assessments have adopted opportunity spectrum methods. There is a group of opportunity spectrum methods that includes various orientations and refinements. This group includes a) ROS (Recreation Opportunity Spectrum); b). TOS (Tourism Opportunity Spectrum); c) LAC (Limits of Acceptable Change); d) TA 
(Threshold Analysis, and more recently e) UET (Ultimate Environmental Thresholds); and $\mathrm{f}$ ) ECOS (Ecotourism Opportunity Spectrum). In this research, ECOS model was used, as presented in Table 1 below.

Table 1. ECOS Model.

\begin{tabular}{|c|c|}
\hline Items & Parameters \\
\hline Accessibility & $\begin{array}{l}\text { To the ecotourism region } \\
\text { To the site (access and } \\
\text { circulation within the } \\
\text { region }\end{array}$ \\
\hline Relationship & $\begin{array}{l}\text { Between ecotourism and } \\
\text { other potential uses of } \\
\text { the same resource } \\
\text { Complementary, } \\
\text { compatibility, } \\
\text { integration, competition }\end{array}$ \\
\hline Attraction & $\begin{array}{l}\text { Types of ecotourism } \\
\text { experience } \\
\text { IN (tropical forests, } \\
\text { mountain areas) } \\
\text { OF (bird, trees, } \\
\text { wildflowers, mammals } \\
\text { BY (watching, filming, } \\
\text { collecting)) }\end{array}$ \\
\hline Infrastructure & $\begin{array}{l}\text { Support infrastructure } \\
\text { Support services }\end{array}$ \\
\hline $\begin{array}{l}\text { User } \\
\text { prerequisites }\end{array}$ & $\begin{array}{l}\text { Prior knowledge } \\
\text { Prior skills } \\
\text { Equipment }\end{array}$ \\
\hline $\begin{array}{l}\text { Social } \\
\text { Interaction } \\
\text { (measurement } \\
\text { by } \\
\text { questionnaire) }\end{array}$ & $\begin{array}{l}\text { Level of interaction } \\
\text { (with other ecotourists) } \\
\text { sought, achieved } \\
\text { Level of interaction with } \\
\text { local/host community } \\
\text { sought, achieved }\end{array}$ \\
\hline $\begin{array}{l}\text { Visitor data } \\
\text { and Impacts } \\
\text { (measurement } \\
\text { by } \\
\text { questionnaire) }\end{array}$ & $\begin{array}{l}\text { Consequences of visitor } \\
\text { access } \\
\text { Controls on visitor } \\
\text { access, use }\end{array}$ \\
\hline Management & $\begin{array}{l}\text { Stakeholder involvement } \\
\text { Decision process }\end{array}$ \\
\hline
\end{tabular}

Refinements of ECOS assessments could include: a) Landscape assessments (to differentiate geographical sectors according to their principal ecotourism resources, stages of 'naturalness'/change, levels of ecotourist interest); b) Attractiveness indices (to differentiate based on uniqueness, international drawing power, primacy - a measure of comparative attraction); c) Resource status (to differentiate according to the degree of disturbance of the natural resource, and any circumstance which might impede sustainability or cause attractiveness to be forfeited - a form of carrying capacity assessment); d). Conservation potential (including rehabilitation potential); e) Marketing assessments (combining some of the other assessments according to an aggregation of attractiveness for particular consumer/tourist market segments - to interpret the feasibility of capturing and sustaining tourist interest).

After analyzing the Spectrum Ecotourism Opportunity in Banda Islands and developing a strategic plan for conservation and development as a marine ecotourism area, it is necessary to develop Conservation Measures Partnership (CMP) as a tool for conservation. The CMP (2013) stated that CMP is a partnership of conservation organizations that seek better ways to design, manage, and measure the impacts of conservation actions. CMP model is improving how conservation impact assessment is measured and accountability. It is a greater chance of designing and implementing effective monitoring and evaluation systems and ultimately, enhancing the program and project design and implementation.

CMP could diagnose why some actions succeed while others do not, including how to plan, implement, and assess conservation actions in the context of a project cycle. It covers: a) the phase of conceptualization: b) defining planning purpose and project team; c) defining the scope, vision, targets; d) identifying critical threats; e) analyzing the conservation situation; f) plan actions and monitoring, 
which consisted of developing goals, strategies, assumptions, and objectives; g) developing monitoring plan; h) developing operational plan; i) implementing actions and monitoring: $\mathrm{j}$ ) developing work plan and timeline; k) developing and refining budget; c) implementing plans; 1) analysing, using, adapting for preparing data for analysis; analyzing results; and adapting strategic plan; Whereas, Capturing and sharing Learning covers: a) document learning; b) sharing learning; c) creating learning environment.

\section{RESULTS AND DISCUSSION}

\subsection{Ecos Model}

Recently, the strategy that has been applied to manage the Banda islands is highly dependent on the central and regional governments. The impact is that the management of the Banda Islands as a marine eco-tourism destination is not optimal. Community involvement has not been optimally utilized, including the role of the private sector. As a result, the management of the Banda Islands has not been able to create significant progress in optimizing the existing potentials, including the involvement of local communities. So, to optimize the existing potential and increase tourist visits, another strategy is needed to develop the tourism sector in the Banda Islands. Internal factors supporting the development of Banda island tourism are the various attractions, the image of the region that has long been known, the community openness, security, and the ease of reaching the location. While that hampers the lack of information tourism centers, the very low nature of the environment, the low human resources, and inadequate supporting infrastructure. The external factors that support the tourism development of the Banda Islands are the accessibility, technological development and information, regulations, and the high potential and interest of tourists. The inhibitors are a cultural intrusion and environmental destruction. In this research, the ECOS used is shown in the table below and the data used to compile the ECOS model derived from Hermalena (2016), Salakory (2016), and Welly et al., (2012).

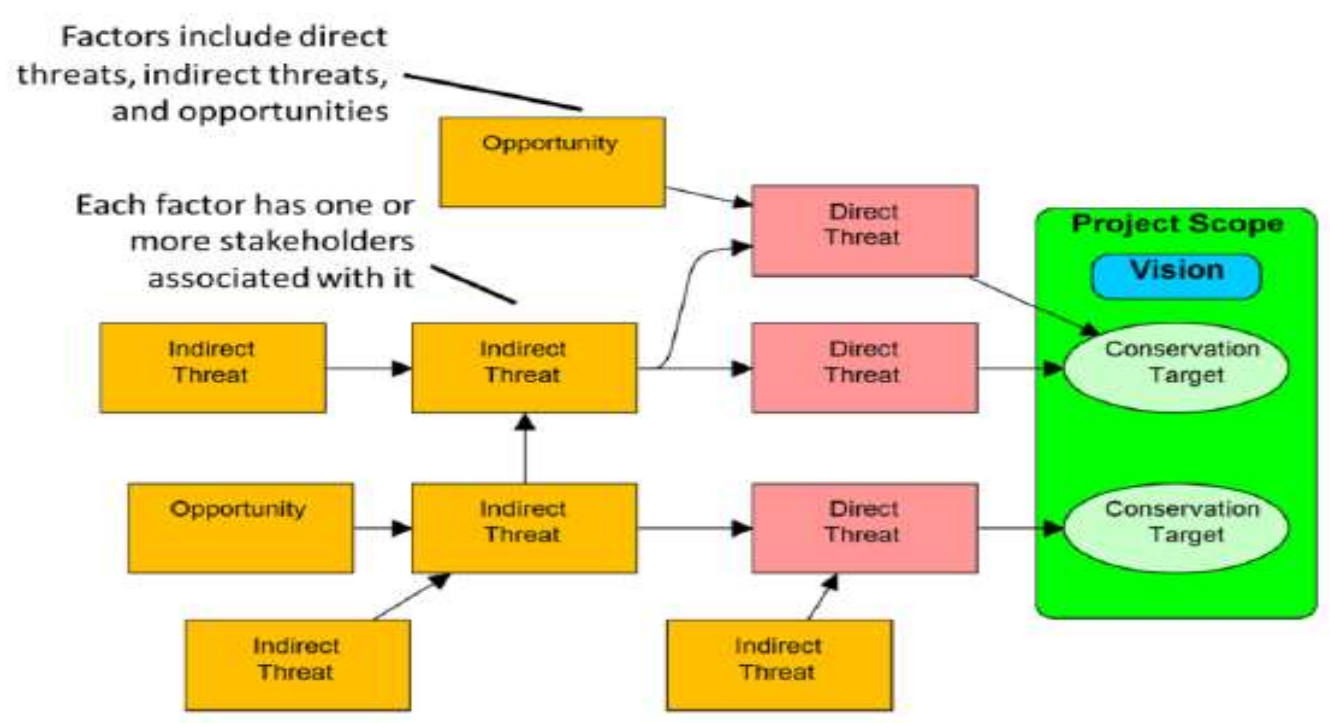

Figure 2. Generic conceptual model showing project context. 
Table 2. ECOS Model.

\begin{tabular}{|c|c|}
\hline Items & Parameters \\
\hline Accessibility & $\begin{array}{l}\text { The transportation routes that can be used to reach Banda Islands from } \\
\text { Ambon are by air and sea travel. Air travel took } 1 \text { hour, while the sea } \\
\text { travel from the city of Ambon takes } 8 \text {-hour travel by Pelni boat and } \\
\text { only about } 2-4 \text { hours by a speedboat. Transportation facilities in the } \\
\text { Banda Islands are dominated by motorcycles and sea transportation } \\
\text { connecting outer villages within the scope of the Banda Islands to the } \\
\text { center of the sub-district. }\end{array}$ \\
\hline Relationship & $\begin{array}{l}\text { Marine ecotourism activities that can be done in Banda Island are } \\
\text { diving and snorkeling with stunning underwater scenery. Besides that, } \\
\text { there are historical places such as castles, houses of the former local } \\
\text { masters, and the house that had been occupied by national movement } \\
\text { figures for six years in exile. Some of these relics have been restored } \\
\text { by the government, which is ready to be marketed as an object of } \\
\text { tourism in the eastern part of Indonesia. }\end{array}$ \\
\hline Attraction & $\begin{array}{l}\text { The people of Banda are cosmopolitan societies. The Banda Islands has } \\
\text { been an area open to the international world since the fifteenth century. } \\
\text { Nations such as Chinese, Arabs, and Malays came to this island, } \\
\text { assimilating with the local population. Besides that, at the beginning of } \\
\text { the 16th century, the Portuguese, Dutch, and English also visited the } \\
\text { island to trade spices. The beauty of the sea in the Banda archipelago } \\
\text { can be enjoyed through several activities such as diving, enjoying the } \\
\text { marine park directly from the boat, fishing for tuna and skipjack, seeing } \\
\text { dolphins and whales and seabirds. Coral reef diversity consists of } 61 \\
\text { genera and } 118 \text { species subgenera. The mollusk diversity comprises } \\
138 \text { gastropods and } 59 \text { bivalves. Other marine tourism that can be } \\
\text { enjoyed is fishing, including seeing whales and dolphins and seabirds. }\end{array}$ \\
\hline Infrastructure & $\begin{array}{l}\text { Other marine tourism that can be enjoyed is fishing, including seeing } \\
\text { whales and dolphins and seabirds. The use of transportation for } \\
\text { transport facilities and services to the Banda islands is considered quite } \\
\text { good. The facilities and infrastructure are now quite supportive of } \\
\text { tourism development, such as roads, clean water, and electricity. The } \\
\text { use of transportation for transportation facilities and services to the } \\
\text { Banda islands is considered good enough and easy to reach the } \\
\text { destination. Transport within the Banda archipelago is quite easy. But } \\
\text { drainage channels are still not good because in some areas there are } \\
\text { experiencing flooding. Clean water service is good enough and can } \\
\text { serve people above } 75 \% \text {. }\end{array}$ \\
\hline $\begin{array}{l}\text { User } \\
\text { prerequisites }\end{array}$ & $\begin{array}{l}\text { To do diving or snorkeling tours visitors must have diving skills. } \\
\text { Before dive, users are required to report things related to prior skills } \\
\text { including their knowledge and experience. Information related to the } \\
\text { various conditions of coral reefs including ornamental fish that will be } \\
\text { encountered during dives becomes important information for divers. } \\
\text { This is intended for the safety of the user himself. }\end{array}$ \\
\hline Social Interaction & $\begin{array}{l}\text { The level of social interaction in the waters of the Banda archipelago is } \\
\text { amazing because the locals are very friendly and easy to demand help }\end{array}$ \\
\hline
\end{tabular}




\begin{tabular}{ll}
\hline \multicolumn{1}{c}{ Items } & Parameters \\
\hline & when there is an end of experiencing distress or difficulty finding the \\
location of the tourist area. This hospitality looks smiling face and mild \\
in favor of help. The diversity of local residents who come from the \\
descendants of foreigners, but its culture becomes a unity in the Banda \\
archipelago. \\
The data of tourist visits from year to year to the Banda archipelago \\
increasing. Visits from foreign tourists in 2008 reached 937 tourists, \\
then in 2009 increased by 1,529 tourists and in 2010 a total of 3,353 \\
tourists. (source of Culture and Tourism Office of Maluku Province, \\
2010). This figure shows that tourism in the Banda archipelago \\
continues to increase every year and this region is a major tourist \\
destination in the central Maluku district. Also, the "Banda sail" event \\
in July-August 2010 contributed to the increasing number of tourists. \\
The impact caused by the performance data shows that visitor interest \\
is very large, so the government must provide various supporting \\
facilities and infrastructure. \\
Management of marine ecotourism areas in the Banda archipelago \\
shows good management. Good management means that the \\
management of the island of Banda has all the facilities provided for \\
the enjoyment of visitors including the ease of reaching vital objects of \\
ecotourism. The security level is very good with a very low-security \\
disturbance indicator. Information media services in providing \\
information to tourists are very good with the number of brochures or \\
information via the internet about the tourism agenda held on various \\
occasions. The price to enter various types of tourist visits both at sea \\
and on land can be reached by visitors at a reasonable price. While the \\
level of cleanliness in various tourist attractions on the island of Banda \\
requires serious attention considering the number of limited janitor and \\
awareness of the population need attention. Going forward, local \\
governments need more community involvement in planning, \\
implementing and monitoring and evaluation processes for the \\
development of the Banda archipelago as a marine ecotourism area. \\
Management
\end{tabular}

Refinements to ECOS assessments
could include landscape assessment,
attractiveness indices, resources status,
conservation potential, marketing
assessment. a) Landscape assessments: the
sea of Banda archipelago played an
important role in trade during the history of
the Banda Islands. Not only was the sea the
only access route to the islands, but it also
provided food for the locals and colonizers.
Nowadays, most people still work as
fishermen and therefore interact daily with
the surrounding coastal environment. In
terms of livelihoods, the fishermen rely heavily on the coral reefs for baitfish to catch the larger fish that are sold commercially. Despite these commercial enterprises, and fitful volcanic eruptions, the coral reef has been proven to possess high resilience. The increasingly high degree of biodiversity is probably due to the buffering effect of the surrounding Banda Sea, which, with its depth of 8000 meters, protects the islands from extreme equatorial temperatures (circa $29^{\circ} \mathrm{C} / 84^{\circ} \mathrm{F}$ throughout the year) and the effects of climate change. This sea also plays an important role in the production of nutmeg, as the sea winds and salty rains 
influence the taste and quality of the nutmeg, which is still claimed to be the best in the world; b) Attractiveness indices: The Island's geological and climatic history, in addition to its resilience to climate change and volcanic activity, has facilitated speciation and high species diversity. However, the coral reefs in the Coral Triangle, particularly in Indonesia and the Philippines, are among the most threatened globally. Therefore, researchers need to discover what causes this high resilience of the reefs, to protect other locations. Moreover, several conservation efforts in the Banda Islands have been successfully made, in which the biodiversity of the coral reef has not only been maintained but even increased. In addition to its scientific importance, Banda Islands play a strategic connective role in migration patterns of several species, one of which is a critical stage in the sea-turtle life cycle. It also gives refuge to highly endangered oceanic cetaceans, including the blue whales. Heikoop et al. (1996) that coral reefs in the Banda archipelago have a good potential of being preserved in the geological record, and could be used to detect volcanic/ hydrothermal events in ancient reef/ volcanic settings. c) Resource status: Since the Banda Islands are surrounded by sea and located in the middle of the Banda Sea, the main livelihood of the people is fishing. Another main livelihood is nutmeg farming, and only a few members of the population are businessmen or employees in a business. The main fisheries are tuna and demersal fish which are fished using simple fishing gears such as bottom hand lines. The population of tuna in the Banda Islands has decreased due to a lack of bait to catch full-size tuna. As a result, young tuna are also being targeted and sold to tuna collecting companies. The communities of the Banda Islands have an indigenous knowledge called Sasi to manage their marine resources, particularly trochus and sea cucumbers. However, Sasi has rarely practiced in the Banda Islands anymore. It is practiced only on Hatta Island, and not on the other islands due to various reasons, such as lack of harvest when the periodic closures are open to fishing (Buka Sasi), or Sasi rules are not obeyed anymore, etc. The Banda Islands have beautiful scenery on both the land and in the sea. Unfortunately, the communities are not yet involved in the tourism activities existing on the islands and they are also not yet receiving any benefits directly, even though the Islands have a huge potential for historic and nature tourism, especially marine tourism. Almost all of the islands have good dive spots, and the coral reefs, fish and other unique marine life under the sea can be a big draw for tourists. d). Conservation potential: The threat of environmental destruction in the Banda Islands due to overfishing, the phenomenon of world climate change, the increasing population increase and the increasingly threatened environmental damage in this area, the government issued decree of the Minister of Marine Affairs and Fisheries of the Republic of Indonesia No. 58/ Ministry Degree of Fisheries and Marine/ 2014 on the Plan Management and Zonation of Banda Marine Aquatic Park in Maluku Province 2014-2034 year on October 6, 2014, which outlines the determination of Banda Islands waters area as Aquatic Marine Park (TWP) Banda sea which is one of the National Conservation Area of Indonesia. The development of the Banda Sea TWP to provide great ecological and economic benefits requires a comprehensive and systematic management direction. Therefore, a long-term management plan of the Banda Marine Aquaculture Park should be developed, be further elaborated into medium and annual plans. e) Marketing assessments: Determination of TWPs of the Banda Islands into Indonesia's national conservation area will enhance local ecological, economic, social and cultural benefits as a harmonization effort between economic exploitation and environmental preservation. The market value offered to tourists both foreign and local tourists means that TWP Banda Island waters provide economic and 
environmental synergies to a region that embraces the principle of sustainable development. The market value principle of TWP Banda Island waters can be an example of other marine ecotourism areas in Indonesia. Based on the analysis of ECOS assessment models and government decisions through the Decree of the Minister of Marine Affairs and Fisheries of the Republic of Indonesia No. 58/ Ministry degree of Fisheries and Marine/ 2014 on Management Plan and Zonation of Banda Marine Aquatic Park in Maluku Province 2014-2034 year on October 6, 2014, that the Banda Islands TWP requires a long-term management plan of the Banda Marine Aquaculture Park that requires translation further for the medium and long term plan. Therefore, a strategic policy plan is needed as a guideline for developing a strategic plan for the development of the Banda Islands TWP. For that purpose, the Conservation Measures Partnership (CMP) method is used as a tool for conservation.

\subsection{Strategic Plan}

The strategic plan needed to harmonize the economic and environmental activities required three policies: environmental preservation, co-management, and institutional development. The preservation policy adheres to the principles used in the development of water conservation area management systems. Preservation area management through integration, participation, multi-stakeholder, with a focus on managing the potential of coral reefs, reef fish, mangrove potential, water clarity with pollution controlled water pollution. Given that the Banda Islands TWP has a unique ecosystem representation, power recoverability, a wide variety of fish, and high biodiversity with biota and physical condition of the environment of natural waters and contains aspects of social, regional and cultural aspects that support the TWP Banda archipelago. The Indonesian Presidential Regulation No. 77 of 2014 concerning Spatial Planning of the Maluku
Islands Number 77 of 2014 Concerning the Spatial Planning of the Maluku Islands states in part one article 5 that the Maluku Islands are a center of marine biodiversity conservation as part of the Coral Triangle) and the protected area serves at least $30 \%$ of the Maluku Islands land area. Article 7 states that strategy for the development of ecotourism-based tourism, cultural tourism, and marine tourism as referred to in paragraph (1) letter includes: a. developing a limited use zone for ecotourism-based tourism, cultural tourism, and marine tourism in conservation areas; b. developing ecotourism-based tourism areas, cultural tourism, and marine tourism; c. developing a national urban area as a center for ecotourism-based tourism development, cultural tourism, and marine tourism; and d. developing transportation infrastructure and facilities to enhance interconnection between tourism designation as well as tourism designation area with a national urban area.

\subsection{Challenges}

The current and future issues are the challenges faced by the management of the Banda Islands. They consisted of (a) overfishing; (b) the use of unfriendly fishing gear; (c) land-use change; (d) marine pollution. These four issues will be a formidable challenge for the management of the Banda Islands waters area. Overfishing is simply the act of catching fish from the oceans faster than the fish can reproduce and replace the caught fish numbers. Modern-day technology and hi-tech equipment have made it easy to catch a larger number of fish in a shorter period and with minimal effort. The more and more fish are caught, the lesser they are found in the waters. This is one of the main reasons that fishermen have to travel longer distances deeper into the sea to catch fish. Welly et al. (2012) mentioned that there has been a decline in fish catch and an increase in operational costs for fishing. The main livelihood of the people is fishing. The Banda Sea is the biggest fishing ground for 
the capture fisheries sector, especially large and small pelagic fisheries. Banda SubDistrict has a potential catch of 1,485.9 tonnes in small pelagic fisheries, taking the $3^{\text {rd }}$ place among the 11 sub-districts in the central of Maluku district. The allowable catch is not more than 594.3 tonnes/ year. Overfishing can occur because the habitat of demersal fish in the Banda Sub-District is very small given that Banda Islands comprise only 11 small islands. Moreover, due to increasing pressure on coastal fisheries and the habitat, the process of restocking would also be slow. Another element that can impact the demersal fisheries sector is the reduction of demersal fish spawning aggregation sites in Banda.

The use of environmentally unfriendly fishing gear in the Banda archipelago was done by traditional fishermen who have not realized that the use of destructive equipment will result in longterm consequences of the destruction of fish habitat. One of the causes of the decline in the number of capture fisheries is that traditional fishermen want catches that can quickly be sold regardless of the damage to coral reefs.

About land-use change in the Banda archipelago, people living on the islands rely on these rich waters for their livelihoods and as a source of food. Fishing has been a mainstay of life for many generations, and the communities on the islands have strong bonds to the sea. However, in recent years, like everywhere in the Coral Triangle, and indeed the world, fish catches have been decreasing. The damage that people around the world are exacting on the ocean, the overextraction, the destructive fishing practices, the pollutants, they are all taking their toll not only in the areas immediately affected, but on all marine life.

Marine pollution in the Banda islands can be caused by some factors. One of the most polluting ones is tourist sewage and domestic waste discharge. Indirect sources of marine pollution include contaminants coming from temporary garbage dumps and unmanaged final dumps. These mostly happen in the marine tourism area. The government has not provided a good place for waste management so that the garbage is scattered and produces bad smell.

Managing the Banda Island cluster as a marine tourism park (TWP) is not optimal yet, although the government has proposed that the management of Banda Islands TWP requires the involvement of the community. The co-management system is an integrated system of right acknowledgment, a partnership of entire fishery stakeholders, including the needs of accommodating them without management, exploitation tends to damage the fishing resources. Given this condition, a sustainable fishery is needed to repair the management system.

\subsection{Conceptual Model for Strategic Plan}

Strategic plan to develop Banda archipelago is used conceptual Model for preparing a strategic plan to develop Banda archipelago as ecotourism and environmental conservation (Figure 3).

The strategic plan from figure 3 can be elaborated as follows: a) The local government of central Maluku regency protects the beaches and headlands from the impacts of inappropriate coastal use that will change the coastal and waters land use. Better environmental regulation is necessary, both to increase positive environmental effects of land-use change and to limit negative influences. The regulation will cover the key drivers of coastal land-use change including sea-level rise, storm surges and flooding, erosion, coastal habitats, demographic trends, tourism, and management realignment. The most profound changes affecting the coastal zone will be driven by climate change, particularly by the rising sea level. The rate of sea-level rise is expected to be substantial and pressures on land use will be significant. Future challenges will have to be confronted if they 
are to be successfully and equitably managed and adapted to the consequences of climate change and the competing human demands on coastal land. Marine and coastal areas should be treated as a single zone. b) Ground fishing mapping is necessary to support sustainable fisheries management. For that required information and valid data. Therefore, the data of fish catch and fishing location from GPS data are combined with a statistical approach. Thus, information on hotspots of fishing areas and potential fishing areas with a better scale can be obtained. Ground fishing mapping should be directed to the greatest benefit to fishermen. Fishing locations should be locations that have easy access for fishermen. The location should be protected from bad weather such as high waves. c) To perform the duties and functions of integration among agencies at the central Maluku district level, the necessary institutional framework that provides appropriate linkage between national authorities, provincial and local. For that, we need an institutional integration between formal and non-formal to begin the planning and implementation of the management of the Banda islands to be effective on the annual term, medium-term and long term. The division of responsibilities overlapping can be overcome by integration tasks and powers between the institutions involved. In establishing an effective management framework, institutional analysis is required, inter alia, the roles and responsibilities of different agencies should be analyzed and, if necessary, revised, so that on the one hand, over-lapping or conflicting jurisdictions are minimized. The institutional integration mechanisms for Banda Island management can ensure the following: first, the appropriate sectoral responsibilities are defined; Second, appropriate integration arrangements are established; and third, all agencies at all levels are informed of the coastal zone policy to ensure coherence in policy implementation.

d) Creating a working forum consisting of local government, local community and private sector will be satisfied that proposed coastal protection works do not unreasonably limit public access to or use of beaches and headlands, or pose a threat to public safety. Any activities that use coastal land and waters require permission from the forum and they will focus on the roles and responsibilities of forum authorities. Provisions for private landowners to establish economic enterprises in coastal areas and water areas, if they do not seek further approval from the forum, their activities will be dismissed in coordination with the law enforcement agencies. The Forum will formulate the policy of managing the Banda Islands to local governments to be established into local regulations. The legal umbrella used is the regulation of the Minister of Marine Affairs and Fisheries No. 58/ Ministry Degree of Fisheries and Marine/ 2014. e) The diversification of the livelihoods of the Banda archipelago is more than just the waters, but it is also related to the economic transformation and the complex nature in which people make decisions in the economy. Communities can make changes in their lives on the principle that their livelihood is sustainable to achieve much greater success in achieving sustainable resource use, rather than a series of alternative livelihood projects that offer a stand-alone life with government rocks. f) The livelihoods of the Banda archipelago community refers to the opportunity to make a distinction between different groups of people who interact and have an impact on the coast. There are four main groups of coastal stakeholders as defined by (Glavovic, 2000). The first is the coastal users, who live and work by the beach and get their livelihood directly from the beach. The second is coastal communities that may live away from the coast but have a direct interest in what is happening along the coastal road. The third is policymakers and government agencies responsible for coastal planning and 
management, and the last is the coastal research community, which provides knowledge and information on how the coastal system works.

Based on the challenges faced in the Banda archipelago, There are 5 (five) strategic plans proposed as priorities. The first priority is creating a working forum; the second one is the integration of tasks among parties involves; the third priority is regulation for coastal land change; the fourth priority is ground fishing mapping and the fifth priority is an alternative livelihood.
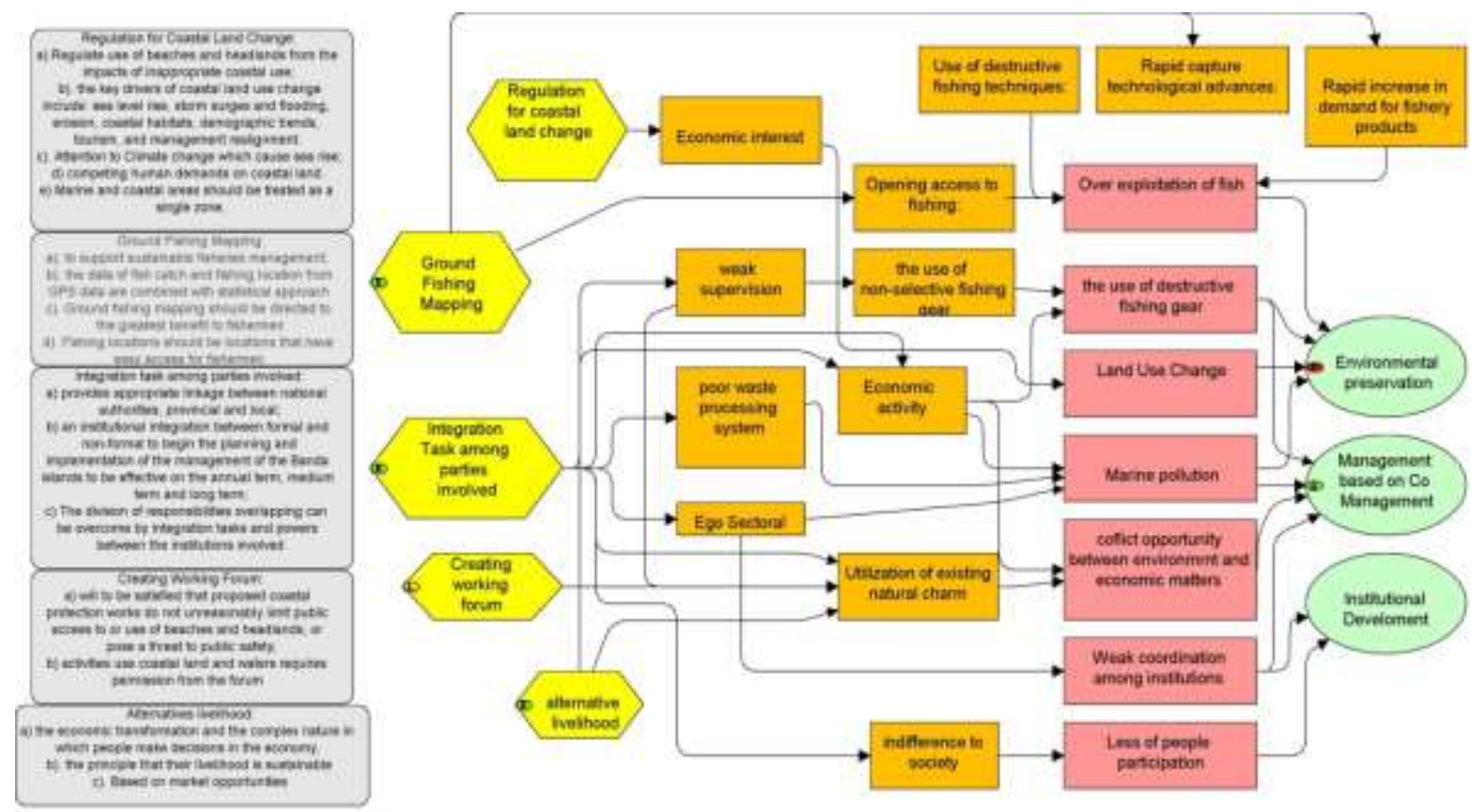

Figure 3. A conceptual model for preparing a strategic plan to develop the Banda archipelago as ecotourism and environmental conservation.

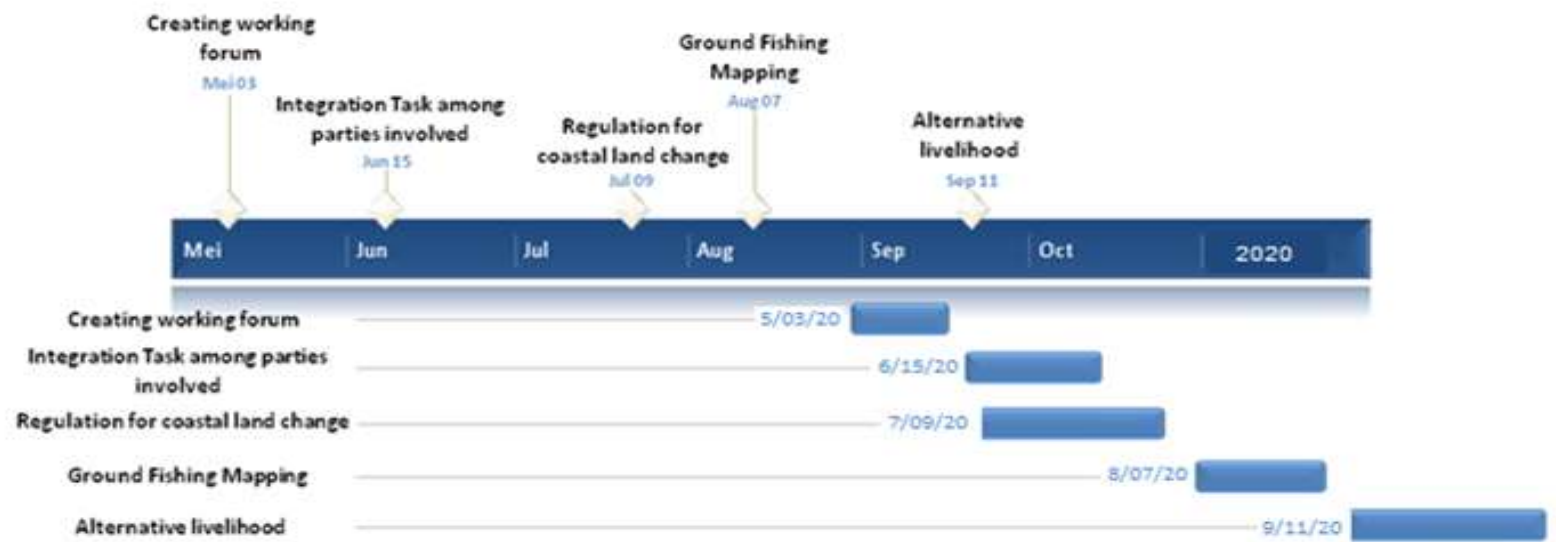

Figure 4. Work plan to implement a strategic plan to develop Banda island as ecotourism and environmental conservation. 


\section{CONCLUSION}

Banda Islands comprising 11 islands are designed as a water park area based on the collaboration between the government, community and private sector. The environmental threats to the Banda islands were not only related to economic issues such as generating income, but also social and environmental issues. Therefore, the management of the Banda Islands must be based on the awareness of all stakeholders for saving the region based on sustainable development. According to the Indonesian Presidential Regulation No. 77 of 2014 concerning Spatial Planning of the Maluku Islands and the regulations of the Ministry of Marine and Fisheries no. 58/ Ministry Degree-Marine Fisheries/ 2014, further elaboration of Banda islands strategic plan is required within the timeframe of the annual plan and medium-term plan. Therefore, it is necessary to formulate a strategic plan concerning local wisdom by using the Fagance model 2015, ECOS (Ecotourism Opportunity Spectrum) and the model of "Conservation Measures Partnership" (CMP). The operational results of the model produce 5 (five) strategic plans the first priority is creating working forum; the second one is the integration of tasks among parties involves; the third priority is regulation for coastal land change; the fourth priority is ground fishing mapping and the fifth priority is an alternative livelihood.

\section{ACKNOWLEDGMENT}

The authors are grateful to the Rector of Brawijaya University, Professor Dr. Ir Nutfil, M.S., who has allowed conducting the research. I also would like to thank to head of research institutes and devotion community of Brawijaya University, Professor Dr. Ir. Woro Busono, M.S. who has helped me complete the research.

\section{REFERENCE}

Budowski. 1977. Tourism and environmental conservation: conflict, coexistence, or symbiosis?. J. Env. Conservation, 3(1): 27-31. https://doi.org/10.1017/S0376892900 017707

Cobbinah, P.B., D. Amanuvor, R. Black, and C. Peprah. 2017. Ecotourism in the Kakum Conservation Area, Ghana: Local politics, practice, and outcome. $J$. of Outdoor Recreation and Tourism, 20: 34-44. https://doi.org/10.1016/j.jort.2017.09. 003

Decree of the Minister of Marine Affairs and Fisheries of the Republic of Indonesia Number 58/Ministry Degree of Fisheries and Marine/2014. 2014. Concerning Management Plan and Zoning of Banda Marine Waters Park in Maluku Province 2014-2034.

Directorate General of Sea Spaces Management, Marine Conservation and Biodiversity, Ministry of Marine Affairs and Fisheries Ministry of Marine Affairs and Fisheries, Downloaded on December 2, 2017. http://kkji.kp3k.kkp.go.id/index.php/b asisdata-kawasankonservasi/details/1/72

Dunster, J. and K. Dunster. 1996. Dictionary of natural resource management. Vancouver: UBC Press. 363 p.

Fagence, Michael. 2015. Strategies for developing ecotourism in Pacific island countries, UNESCAP/SPTO Seminar on Sustainable Development of Ecotourism in Pacific Island Countries. Presentation to UNESCAP/SPTO Seminar on Sustainable Development of Ecotourism in Pacific Island Countries Suva, Fiji October, 2001 download on 11 September 2018. 
Heikoop, M.J., C.J. Tsujita, M.J. Risk, and T. Tomascik. 1996. Corals as proxy recorders of volcanic activity: evidence from Banda Api, Indonesia. PALAIOS, 11(3): 286-292. http://doi.org/10.2307/3515236

Hermalena, and Leffy. 2016. Economic Valuation of Banda Sea National Conservation Area, Maluku Province, National Seminar on Maritime, Science and Applied Technology 2016 (1) ISSN: 2548 - 15095.

Huffard, C.L., M.V. Erdmann, T. Gunawan. 2009. Defining geographic priorities for marine biodiversity conservation in indonesia, conservation international Indonesia. 103 p.

Khoshtaria, T.K, and N.T. Chachava. 2017. Prospects of ecotourism development in recreation areas of South Georgia. Annals of Agrarian Science, 15(3): 312-317. https://doi.org/10.1016/j.aasci.2017.0 7.004

Lindberg, K., J. Enriquez, and K. Sproule. 1997. Ecotourism questioned: case studies from Belize. Annals of Tourism Research, 23(3): 543-562. https://doi.org/10.1016/01607383(95)00074-7

The President Republic of Indonesia. 2014. Indonesian Presidential Regulation
No. 77 of 2014 Concerning Spatial Planning of the Maluku Islands, The copy is following the original Secretariat Cabinet RI Deputy for Economic Affairs.

Salakory, R.A.J.B. 2016. Pengembangan ekowisata berbasis masyarakat di Kepulauan Banda, Kabupaten Maluku Tengah. J. Ilmu-ilmu Pertanian "AGRIKA", 10(1): 84-92. https://doi.org/10.31328/ja.v10i1.441

The Conservation Measures Partnership. 2013. Open Standards for The Practice of Conservation, Version 3.0. April 2013. 47 p.

Welly, M., R. Djohani, Suharsono., A. Green, M. Korebima, Y. Hehuat, R. Alik, and N. Rijoli. 2012. Marine Rapid Assessment of the Banda Islands, Maluku Tengah, Indonesia. Coral Triangle Center. 166 p.

Wallace, G. N., and S. Pierce. M.1996. An evaluation of ecotourism in Amazon, Brazil. Annals of Tourism Research 23(4): 843-873. https://doi.org/10.1016/01607383(96)00009-6
Received :02 January 2019
Reviewed : 10 October 2019
Accepted : 25 November 2019 
